\title{
Resistance of sweet potato clones to meloidogyne incognita races 1 and 3
}

\author{
Jorge Augusto Assis Gomes ( $\left.{ }^{1}\right)$; Valter Carvalho Andrade Júnior $\left({ }^{2}\right)$; Celso Mattes de Oliveira $\left({ }^{1 *}\right)$; \\ Alcinei Mistico Azevedo (3); Wilson Roberto Maluf ('); Luiz Antonio Augusto Gomes (') \\ (') Universidade Federal de Lavras (UFLA), Departamento de Agricultura, Caixa Postal 3037, 37200-000 Lavras (MG), Brasil. \\ (2) Universidade Federal dos Vales do Jequitinhonha e Mucuri (UFVJM), Departamento de Agronomia, \\ Rua da Glória, 187, 39100-000 Diamantina (MG), Brasil. \\ (3) Universidade Federal de Viçosa (UFV), Avenida Peter Henry Rolfs, s/n, 36570-900 Viçosa (MG), Brasil. \\ (*) Corresponding author: celsodoliveira@yahoo.com.br
}

Received: Dec. 17, 2014; Accepted: Mar. 16, 2015

\begin{abstract}
The objective of this study was to evaluate sweet potato clones for resistance to root-knot nematode, Meloidogyne incognita races 1 and 3. For each nematode physiological race, a greenhouse experiment was set up in a randomized block experimental design with three replications and six plants per plot. Fifty-eight sweet potato clones from the UFVJM germplasm bank were evaluated, plus five commercial cultivars (Brazlândia Rosada, Brazlândia Branca, Palmas, Princesa and Coquinho), plus the cv. Santa Clara tomato (susceptible to Meloidogyne spp.). Stems were planted in 72-cell expanded polystyrene trays, filled with commercial substrate and inoculated with the pathogen thirty days after planting. Forty-five days after inoculation, the eggs were extracted, counted, and later evaluated. Resistance level classification was performed based on reproduction factor (RF) and reproduction index (RI). Among the 63 analyzed clones, a percentage of $78 \%$ were classified as resistant to $M$. incognita race $1.79 \%$ to race 3 and $67 \%$ showed multiple resistance to both $M$. incognita races.
\end{abstract}

Key words: Ipomoea batatas, root-knot nematode, breeding, pathogen, reproduction factor, reproduction index.

\section{INTRODUCTION}

The sweet potato, Ipomoea batatas (L.) Lam., is a vegetable of great social, economic and nourishing importance, especially for the poorest regions of the planet, where it is one of the most important food sources (Oliveira et al., 2005).

Despite showing high yield potential, Brazilian yield is still low, due to - among other problems - the little care in crop management, the planting of obsolete and degenerated genetic materials and the use of cultivars which in their majority are susceptible the root-knot nematode (Marchese et al., 2010; Kalkmann et al., 2013). Among the major sweet potato pests, root-knot nematodes, Meloidogyne spp., are one of the most destructive for the crop. They are widely distributed and present higher problems when cultivated in tropic, subtropic and warm temperature regions worldwide (Jatala, 1991), being considered one of the determining factors for Brazilian low yield (Neves et al., 2010).

According to Rosa et al. (2013), among the major nematode species found in areas for vegetable crops, M. incognita and $M$. javanica may be found concurrently or separately. On a global scale, Meloidogyne incognita is the most important nematode species that attacks sweet potato, and the only Meloidogyne species with global distribution (Jatala, 1991).

Four M. incognita races (races 1, 2, 3 and 4) are currently known, and their ability to parasitize the host vary according to crop susceptibility. However, according to results obtained by Chaves et al. (2013), Charchar \& Ritschel (2004), Kalkmann et al. (2013) and Marchese et al. (2010), all four races have the ability to parasitize sweet potato.

Although some Meloidogyne species are able to migrate to shoot and cause lesions on leaves and seeds (Michereff et al., 2005), the infection occurs in root system. To sustain feeding, nematodes drastically convert the susceptible host root cells into elaborate feeding cells, including complex nodulation, changes in cell gene expression, physiology, morphology and function (Hussey et al., 2002). Parasitism reflections may be the most varied, ranging from root necrosis to nutrient absorption and translocation alterations (Marino et al., 2012), and 
the most common symptom is root-knot formation at various sizes and shapes.

There are several nematode controlling methods, such as crop rotation, use of nematicides, among others. However, these methods are not always suitable for farmers, nor economically viable (Baldin et al., 2012). According to Ferreira et al. (2010), the most feasible and promising control strategy is the use of resistant cultivars. In recent years, several sweet potato cultivars and clones were selected in Brazil for resistance to root-knot nematodes, especially for $M$. incognita races 1,2 , 3 and 4 and $M$. javanica (Chaves et al., 2013; Charchar \& Ritschel, 2004; Kalkmann et al., 2013; Maluf et al., 1996; Marchese et al., 2010; Massaroto et al., 2010).

Meanwhile, according to Neves et al. (2010), genetic resistance control, although desirable, is limited by lack of resistant cultivars. Thus, the objective of this study was to evaluate sweet potato clones for resistance to physiologic races 1 and 3 of $M$. incognita.

\section{MATERIAL AND METHODS}

Two independent experiments were carried out to test sweet potato clones resistance to the Meloidogyne incognita physiological races 1 and 3. The experiments were conducted at the Experimental Vegetable Station of HortiAgro Sementes Ltda., Palmital Farm, Ijaci County, MG, located at $21^{\circ} 14^{\prime} 16^{\prime \prime} S$ and $45^{\circ} 08^{\prime} 00^{\prime \prime} \mathrm{W}$, with an average altitude of $918 \mathrm{~m}$.

A total of 63 sweet potato clones were evaluated, being five commercial cultivars (Brazlândia Rosada, Brazlândia Branca, Palmas, Princesa and Coquinho), and fifty-eight clones from the germplasm bank of the Universidade Federal dos Vales do Jequitinhonha e Mucuri (UFVJM). These clones originated in different regions of the country, with emphasis on the Jequitinhonha and Mucuri Valleys, being part of the genetic breeding programs of the institution. Besides sweet potato clones, tomato plants (Solanum lycopersicum), cultivar Santa Clara, were used to check the quality of the inoculum.

The experiments were set and conducted in greenhouses. Planting of the materials related to races 3 and 1 of Meloidogyne incognita were carried out on 11/21/2012 and 3/7/2013, respectively. Stems of each clone were standardized to $20 \mathrm{~cm}$ long and with three to four internodal buds; they were planted in 72-cell polystyrene trays filled with Plantmax ${ }^{\circledR}$ commercial substrate. In order to verify nematode-egg suspension efficiency, tomato seeds (control treatment, susceptible to Meloidogyne spp.) were sown at the ends of each tray, 15 days after sweet potato planting.

As inoculum source, it was used races 1 and 3 of Meloidogyne incognita from highly infected susceptible tomato plants that were grown under greenhouse. The inoculum was obtained according to method described by Hussey \& Barker (1973). Thus, after washed, tomato roots for each trial were chopped and processed in a blender for 30 seconds in a sodium hypochlorite solution at $0.5 \%$. After this process, solution was poured into a $0.074 \mathrm{~mm}$ sieve placed over a $0.028 \mathrm{~mm}$ sieve, under abundant running water. Root remains were retained on the $0.074 \mathrm{~mm}$ sieve, while on $0.028 \mathrm{~mm}$ nematode eggs were collected, being transferred to a beaker with the aid of a wash-bottle with pure water. To proceed egg counting, beaker volume was initially adjusted with water to $1,000 \mathrm{~mL}$ and egg suspension was homogenized. Subsequently, using a pipette, three $1 \mathrm{~mL}$ aliquots of the suspension were transferred into the Peter's chamber and brought into a stereomicroscope where egg average number per $\mathrm{mL}$ of solution was quantified. Following egg counting, suspension at the desired concentration was formulated (1,000 eggs $/ \mathrm{mL})$.

Race 3 inoculation was carried out on 12/20/2012, and race 1 on 4/8/2013. It was performed a uniform distribution on plant collar using a veterinary syringe with 2,500 and 3,500 M. incognita eggs per plant of race 1 and 3, respectively. Inoculum viability was evaluated in a hatching chamber, reaching $60 \%$ and $63 \%$ of viable eggs. Thus, the amount of viable eggs applied per plant was 1,516 and 2,205 respectively.

It was performed a complete randomized block experimental design with 63 treatments (clones) plus Santa Clara tomato cultivar (susceptible control) and three repetitions of six plants per plot. Six expanded polystyrene trays composed each block, each one containing 11 rows of six plants with sweet potato clones and 1 row with tomato plants.

After 45 days of inoculation, on 2/4/2013 and 23/5/2013, sweet potato and tomato plants referring respectively to the experiments with Meloidogyne incognita races 3 and 1 were carefully removed from substrate and roots washed to extract the eggs, according to method proposed by Hussey \& Barker (1973). The estimated number of eggs was calculated by counting $1 \mathrm{~mL}$ of suspension in Peter's chamber. The total number of eggs was determined by extrapolation of values obtained on this count, which corresponded to the final nematode population (Pf). From these data, the following variables were determined: Reproduction factor (RF) and Reproduction index (RI). According to model proposed by Oostenbrink (1966), RF corresponds to the ratio between final and initial nematode population $(\mathrm{RF}=\mathrm{Pf} / \mathrm{Pi})$ and is used to determine resistance $(\mathrm{RF}<1)$ and susceptibility $(\mathrm{RF} \geq 1)$.

To determine $M$. incognita $\mathrm{RI}$, tomato plants were taken as standard control (100\%) in comparison to nematode reproduction in sweet potato. The final population values (Pf) found for sweet potato clones were divided by the ones found for tomato, thereby obtaining RI values (\%). Thus, resistance of each sweet potato genotype to Meloidogyne incognita was determined according to classification of Taylor (1967). This classification states plants as susceptible (S) with normal reproduction and RI above 51\%; slightly resilient (SR), RI from 26 to 50\%; moderately resistant (MoR), RI 
from 11 to $25 \%$; very resistant plant (VR), RI from 1 to $10 \%$; and highly resistant/ immune (HR/I), RI below $1 \%$.

For statistical analysis, it was used average values by plot. To meet variance analysis assumptions, values of the evaluated variables were transformed into log scores using $\log (x+2)$. Data were subjected to variance analysis, and when significant effect was observed by "F" test, averages were grouped by Scott \& Knott test at 5\% probability. Heritability in broad sense $\left(\mathrm{h}_{\mathrm{a}}^{2}\right)$ was also estimated, as well as genetic variation coefficient $\left(\mathrm{CV}_{\mathrm{g}}\right)$, environmental variation coefficient $\left(\mathrm{CV}_{\mathrm{e}}\right)$ and relative variation coefficient $\left(\mathrm{CV}_{\mathrm{r}}\right)$.

The statistical analyses were performed with aid of GENES genetic statistical software (Cruz, 2013).

\section{RESULTS AND DISCUSSION}

Table 1 presents the summary of mean squares and estimates of genetic parameters. There was a significant effect $(p<0.001)$ among treatments for RF and RI in both physiological races. Kalkmann et al. (2013), Marchese et al. (2010) and Massaroto et al. (2010), have verified similar resuts of differences in resistance to Meloidogyne spp among evaluated samples.

Genetic variation coefficient values were considered superior to environmental ones, thus, indicating plant selection as a good tool (Gonçalves et al., 2012). Relative variation coefficient indicated by the ratio between $\mathrm{CV}_{\mathrm{g}}$ and $\mathrm{CV}_{\mathrm{e}}$, presented values higher than 1.00 , except the reproduction index in race 1 , which again indicates a very favorable situation for selection.

Heritability in broad sense for RF and RI were higher than $90 \%$ and $70 \%$ respectively in both nematode races. Kalkmann et al. (2013) and Marchese et al. (2010) also verified high heritability values in experiments involving sweet potato clone selection for root-knot nematode resistance. According to Neves et al. (2010), heritability estimates are fundamental in plant breeding programs, since they express reliability with which phenotypes represent genotypes.

When observing the reaction of sweet potato clones regarding race 1 resistance, it was found that $78 \%$ of the clones showed resistance in compliance with classification proposed by Oostenbrink (1966) (Table 2). Based on this classification, these clones are suitable for cultivation in infested areas with $M$. incognita race 1 , or being used as resistance sources for plant breeding programs.

Clone classification according to Oostenbrink (1966) is confirmed by Scott \& Knott group, in which resistant clone averages differ $(\mathrm{p}<0.05)$ from control (tomato plants). When associating Oostenbrink classification and Scott \& Knott grouping, it is verified that the clones considered susceptible by the classification (Oostenbrink, 1966) showed averages in four distinct groups by Scott \& Knott grouping. Thus, even when classified as susceptible by Oostenbrink (1966), clones may show resistance levels variables.

Considering Taylor (1967) classification, only the cv. Santa Clara tomato appeared as susceptible by RI (Table 2). All 63 sweet potato clones showed some resistance, 35\% being classified as highly resistant/immune (HR/I), 52\% very resistant (VR), and only $11.10 \%$ and $1.60 \%$ were classified as moderately resistant (MoR) slightly resistant (SR), respectively.

Among evaluated clones, nineteen are in common with Massaroto et al. (2010), who used classification proposed by Huang et al. (1986), which resembles Taylor classification for being based on class distribution due to resistance, found that several clones from the UFVJM germplasm bank presents resistance varying from moderate to high, what corroborated with the present study.

As observed by Oostenbrink classification (Oostenbrink, 1966), clones showed high resistance to race 1 by Taylor classification (Taylor, 1967), indicating that they are poor hosts for the pathogen. There has been reported a high frequency of clones resistant to $M$. incognita race 1 in experiments with sweet potatoes. Marchese et al. (2010)

Table 1. Summary of mean squares and genetic parameters for reproduction factor (RF) and reproduction index (RI) of Meloidogyne incognita (races 1 and 3) sweet potato clones. UFVJM, Diamantina (MG), 2013

\begin{tabular}{|c|c|c|c|c|c|}
\hline \multirow{3}{*}{$\begin{array}{l}\text { Fontes de } \\
\text { Variação }\end{array}$} & \multirow{3}{*}{ GL } & \multicolumn{4}{|c|}{ Meloidogyne incognita } \\
\hline & & \multicolumn{2}{|c|}{ Raça 1} & \multicolumn{2}{|c|}{ Raça 3} \\
\hline & & Fator de Reprodução & Índice de Reprodução & Fator de Reprodução & Índice de Reprodução \\
\hline Blocos & 2 & $0.0002 \mathrm{~ns}$ & $0.0055^{* *}$ & $0.3078^{* *}$ & $0.0112^{* *}$ \\
\hline Tratamentos & 62 & $0.2553^{* *}$ & $0.0026^{* *}$ & $0.3728^{* *}$ & $0.0144^{* *}$ \\
\hline Resíduo & 124 & 0.0255 & 0.0007 & 0.0240 & 0.0013 \\
\hline MÉDIA $(\mu)$ & & 0.9413 & 0.7134 & 0.9767 & 0.7347 \\
\hline $\mathrm{h}_{\mathrm{a}}^{2}(\%)$ & & 90.0118 & 73.0769 & 93.5622 & 90.9722 \\
\hline $\mathrm{CV}_{\mathrm{e}}^{\mathrm{a}}(\%)$ & & 16.9641 & 3.7088 & 15.8610 & 4.9078 \\
\hline $\mathrm{CV}_{\mathrm{g}}(\%)$ & & 29.4019 & 3.5277 & 34.9101 & 8.9947 \\
\hline $\mathrm{CV}_{\mathrm{r}}$ & & 1.7332 & 0.9512 & 2.2010 & 1.8328 \\
\hline
\end{tabular}

Environmental variation coefficient (CVe); Genetic variation coefficient (CVG); Relative coefficient of variation (CVr); Herdability in the broad sense ( ). ns e ** not significant and significant at $1 \%$ probability respectively, by F Test. Data expressed as $\log (\mathrm{x}+2)$ where $\mathrm{x}$ is the value of the reproduction rate and reproduction index. 
Table 2. Average of reproductive factors (RF) and reproduction index (RI\%) of Meloidogyne incognita (Race 1 and 3 ) in 63 clones sweet potato evaluated and tomato cultivar Santa Clara, and classification (2, 3 ) of these clones for resistance or susceptibility to nematodes. UFVJM, Diamantina (MG) 2013

\begin{tabular}{|c|c|c|c|c|c|c|c|c|}
\hline \multirow{4}{*}{ Clones } & \multicolumn{8}{|c|}{ Meloidogyne incognita } \\
\hline & \multicolumn{4}{|c|}{ Raça 1} & \multicolumn{4}{|c|}{ Raça 3} \\
\hline & \multicolumn{2}{|c|}{ Fator de Reprodução } & \multicolumn{2}{|c|}{ Índice de Reprodução } & \multicolumn{2}{|c|}{ Fator de Reprodução } & \multicolumn{2}{|c|}{ Índice de Reprodução } \\
\hline & FR & Classe & IR (\%) & Classe & FR & Classe & IR (\%) & Classe \\
\hline Arruba & $0.35^{(1)} \mathrm{a}$ & $\mathrm{R}^{(2)}$ & $2.16 \mathrm{a}$ & $\mathrm{MR}^{(3)}$ & $0.35 a$ & $\mathrm{R}$ & $3.34 a$ & MR \\
\hline Batata mandioca & $0.00 \mathrm{a}$ & $\mathrm{R}$ & $0.00 \mathrm{a}$ & AR/I & $10.50 f$ & S & $108.54 \mathrm{e}$ & S \\
\hline Brazlândia Branca & $0.40 a$ & $\mathrm{R}$ & $2.68 \mathrm{a}$ & MR & $0.32 \mathrm{a}$ & $\mathrm{R}$ & $3.18 \mathrm{a}$ & MR \\
\hline Brazlândia Rosada & $0.13 a$ & $\mathrm{R}$ & $0.95 a$ & AR/I & $0.14 a$ & $\mathrm{R}$ & $1.58 \mathrm{a}$ & MR \\
\hline Cambraia & $2.58 c$ & S & $15.96 b$ & MoR & $2.09 d$ & S & $21.85 b$ & MoR \\
\hline Cariru vermelha & $4.09 d$ & S & $22.67 c$ & MoR & $0.94 b$ & $\mathrm{R}$ & $9.27 \mathrm{a}$ & MR \\
\hline Coquinho & $0.00 \mathrm{a}$ & $\mathrm{R}$ & $0.00 \mathrm{a}$ & $A R / I$ & $0.09 a$ & $\mathrm{R}$ & $0.91 \mathrm{a}$ & AR/I \\
\hline Espanhola & $0.69 b$ & $\mathrm{R}$ & $3.63 a$ & MR & $1.63 c$ & $S$ & $14.81 \mathrm{~b}$ & MoR \\
\hline Licuri & 0.18 & $R$ & $1.08 \mathrm{a}$ & MR & $0.31 a$ & $\mathrm{R}$ & $2.90 a$ & MR \\
\hline Palmas & $0.51 \mathrm{a}$ & $\mathrm{R}$ & $2.57 a$ & MR & $0.05 a$ & $\mathrm{R}$ & $0.44 a$ & $\mathrm{AR} / \mathrm{I}$ \\
\hline Princesa & $1.58 \mathrm{~b}$ & S & $10.08 b$ & MR & $3.40 \mathrm{~d}$ & $S$ & $32.33 c$ & LR \\
\hline T Carro 1 & $1.63 b$ & $S$ & $10.61 b$ & MR & $1.86 c$ & $S$ & $18.78 b$ & MoR \\
\hline T Carro 2 & $0.18 a$ & $\mathrm{R}$ & $1.07 \mathrm{a}$ & MR & $0.01 a$ & $\mathrm{R}$ & $0.12 \mathrm{a}$ & $\mathrm{AR} / \mathrm{I}$ \\
\hline UFVJM-01 & $0.56 a$ & $\mathrm{R}$ & $3.47 a$ & MR & $0.10 a$ & $\mathrm{R}$ & $1.04 a$ & MR \\
\hline UFVJM-02 & $3.51 \mathrm{~d}$ & $S$ & $20.64 c$ & MoR & $0.05 a$ & $\mathrm{R}$ & $0.52 a$ & $A R / I$ \\
\hline UFVJM-03 & $4.09 d$ & S & $22.09 c$ & MoR & $0.64 b$ & $\mathrm{R}$ & $5.98 a$ & MR \\
\hline UFVJM-04 & $2.00 c$ & $S$ & $11.21 b$ & MoR & $1.50 \mathrm{c}$ & $S$ & $15.09 b$ & MoR \\
\hline UFVJM-05 & $0.00 a$ & $\mathrm{R}$ & $0.00 \mathrm{a}$ & AR/I & $0.11 a$ & $\mathrm{R}$ & $0.96 a$ & $A R / I$ \\
\hline UFVJM-06 & $0.00 a$ & $\mathrm{R}$ & $0.00 \mathrm{a}$ & AR/I & $0.26 a$ & $R$ & $3.07 a$ & MR \\
\hline UFVJM-08 & $1.04 b$ & $S$ & $5.21 \mathrm{a}$ & MR & $4.15 \mathrm{e}$ & $S$ & $41.96 d$ & LR \\
\hline UFVJM-09 & $0.07 a$ & $\mathrm{R}$ & $0.18 \mathrm{a}$ & AR/I & $0.14 a$ & $R$ & $1.36 a$ & MR \\
\hline UFVJM-10 & $0.18 a$ & $\mathrm{R}$ & $0.87 a$ & AR/I & $0.17 a$ & $\mathrm{R}$ & $1.98 a$ & MR \\
\hline UFVJM-13 & $0.35 a$ & $R$ & $1.94 \mathrm{a}$ & MR & $0.84 b$ & $R$ & $8.18 a$ & MR \\
\hline UFVJM-14 & $0.51 a$ & $\mathrm{R}$ & $2.78 a$ & MR & $0.63 b$ & $\mathrm{R}$ & $5.93 a$ & MR \\
\hline UFVJM-17 & $0.62 b$ & $\mathrm{R}$ & $3.67 a$ & MR & $0.39 a$ & $\mathrm{R}$ & $3.83 a$ & MR \\
\hline UFVJM-19 & $0.81 b$ & $\mathrm{R}$ & $4.86 a$ & MR & $0.00 a$ & $\mathrm{R}$ & $0.00 a$ & $A R / I$ \\
\hline UFVJM-21 & $0.34 a$ & $\mathrm{R}$ & $1.71 \mathrm{a}$ & MR & $3.05 d$ & $S$ & $29.38 c$ & LR \\
\hline UFVJM-22 & $0.93 b$ & $\mathrm{R}$ & $5.76 a$ & MR & $3.14 d$ & $S$ & $30.75 c$ & LR \\
\hline UFVJM-23 & $0.20 \mathrm{a}$ & $\mathrm{R}$ & $1.18 \mathrm{a}$ & MR & $0.43 a$ & $\mathrm{R}$ & $4.12 \mathrm{a}$ & MR \\
\hline UFVJM-24 & $2.19 c$ & $S$ & $11.29 b$ & MoR & $0.92 b$ & $\mathrm{R}$ & $8.36 a$ & MR \\
\hline UFVJM-25 & $0.49 a$ & $\mathrm{R}$ & $2.92 \mathrm{a}$ & MR & $0.20 a$ & $\mathrm{R}$ & $1.97 a$ & MR \\
\hline UFVJM-26 & $0.26 a$ & $\mathrm{R}$ & $1.32 \mathrm{a}$ & MR & $0.67 b$ & $\mathrm{R}$ & $5.91 \mathrm{a}$ & MR \\
\hline UFVJM-27 & $1.02 \mathrm{~b}$ & $S$ & $5.93 a$ & MR & $0.39 a$ & $\mathrm{R}$ & $3.69 a$ & MR \\
\hline UFVJM-28 & $0.44 a$ & $R$ & $2.20 \mathrm{a}$ & MR & $0.40 a$ & $\mathrm{R}$ & $3.35 a$ & MR \\
\hline UFVJM-30 & $0.09 a$ & $R$ & $0.64 a$ & $A R / I$ & $0.21 a$ & $\mathrm{R}$ & $1.96 a$ & MR \\
\hline UFVJM-31 & $0.00 a$ & $\mathrm{R}$ & $0.00 \mathrm{a}$ & $\mathrm{AR} / \mathrm{I}$ & $0.22 a$ & $R$ & $2.36 a$ & MR \\
\hline UFVJM-32 & $0.09 a$ & $\mathrm{R}$ & $0.24 a$ & AR/I & $0.08 a$ & $R$ & $0.74 a$ & $A R / I$ \\
\hline UFVJM-33 & $0.11 \mathrm{a}$ & $\mathrm{R}$ & $0.50 \mathrm{a}$ & $\mathrm{AR} / \mathrm{I}$ & $0.28 a$ & $\mathrm{R}$ & $2.71 a$ & MR \\
\hline UFVJM-34 & $5.21 \mathrm{~d}$ & S & $31.99 c$ & LR & $0.10 a$ & $R$ & $0.82 a$ & AR/I \\
\hline UFVJM-35 & $0.00 a$ & $\mathrm{R}$ & $0.00 \mathrm{a}$ & AR/I & $0.38 a$ & $\mathrm{R}$ & $3.49 a$ & MR \\
\hline UFVJM-36 & $0.26 a$ & $\mathrm{R}$ & $1.76 \mathrm{a}$ & MR & $0.69 b$ & $R$ & $6.92 a$ & MR \\
\hline UFVJM-37 & $0.00 a$ & $\mathrm{R}$ & $0.00 \mathrm{a}$ & $\mathrm{AR} / \mathrm{I}$ & $0.04 a$ & $\mathrm{R}$ & $0.37 a$ & $A R / I$ \\
\hline UFVJM-38 & $0.13 a$ & $\mathrm{R}$ & $0.95 a$ & AR/I & $0.22 a$ & $\mathrm{R}$ & $1.66 \mathrm{a}$ & MR \\
\hline UFVJM-39 & $0.14 a$ & $R$ & $0.80 \mathrm{a}$ & AR/I & $0.13 a$ & $R$ & $1.10 \mathrm{a}$ & MR \\
\hline UFVJM-40 & $0.91 b$ & $\mathrm{R}$ & $4.59 a$ & MR & $1.62 c$ & S & $16.16 \mathrm{~b}$ & MoR \\
\hline UFVJM-43 & $0.38 a$ & $R$ & $2.58 \mathrm{a}$ & MR & $0.06 a$ & $R$ & $0.89 a$ & $\mathrm{AR} / \mathrm{I}$ \\
\hline UFVJM-44 & $0.16 a$ & $\mathrm{R}$ & $0.99 a$ & AR/I & $0.51 a$ & $\mathrm{R}$ & $5.04 a$ & MR \\
\hline UFVJM-45 & $0.09 a$ & $R$ & $0.64 a$ & $A R / I$ & $0.60 b$ & $\mathrm{R}$ & $5.66 a$ & MR \\
\hline
\end{tabular}

${ }^{(1)}$ Means followed by the same letter in the column do not differ by the Scott-Knott test at $5 \%$ probability, Medium expressed based on the untransformed data. ${ }^{(2)} \mathrm{R}$, resistant; $\mathrm{S}$, susceptible. ${ }^{(3)}$ S, susceptible (Standard), IR above 51\%; LR slightly resilient, IR 26-50\%; Mor moderately resistant, IR 11-25\%; MR, very tough, IR 1\% to 10\%; AR / I, highly resistant / immune, IR below $1 \%$. 
Table 2. Continued...

\begin{tabular}{|c|c|c|c|c|c|c|c|c|}
\hline \multirow{4}{*}{ Clones } & \multicolumn{8}{|c|}{ Meloidogyne incognita } \\
\hline & \multicolumn{4}{|c|}{ Raça 1} & \multicolumn{4}{|c|}{ Raça 3} \\
\hline & \multicolumn{2}{|c|}{ Fator de Reprodução } & \multicolumn{2}{|c|}{ Índice de Reprodução } & \multicolumn{2}{|c|}{ Fator de Reprodução } & \multicolumn{2}{|c|}{ Índice de Reprodução } \\
\hline & FR & Classe & IR (\%) & Classe & FR & Classe & IR (\%) & Classe \\
\hline UFVJM-46 & $0.09 a$ & $\mathrm{R}$ & $0.64 a$ & AR/I & $0.37 a$ & $\mathrm{R}$ & $3.63 a$ & MR \\
\hline UFVJM-47 & $0.27 a$ & $\mathrm{R}$ & $1.41 \mathrm{a}$ & MR & $0.60 b$ & $\mathrm{R}$ & $5.89 a$ & MR \\
\hline UFVJM-48 & $0.03 a$ & $\mathrm{R}$ & $0.24 a$ & AR/I & $0.26 \mathrm{a}$ & $\mathrm{R}$ & $2.25 \mathrm{a}$ & MR \\
\hline UFVJM-49 & $0.17 a$ & $\mathrm{R}$ & $1.04 \mathrm{a}$ & MR & $0.02 \mathrm{a}$ & $\mathrm{R}$ & $0.14 \mathrm{a}$ & AR/I \\
\hline UFVJM-50 & $0.24 a$ & $\mathrm{R}$ & $1.36 \mathrm{a}$ & MR & $0.24 a$ & $\mathrm{R}$ & $2.38 \mathrm{a}$ & MR \\
\hline UFVJM-51 & $0.08 a$ & $\mathrm{R}$ & $0.41 a$ & AR/I & $0.37 a$ & $\mathrm{R}$ & $3.59 a$ & MR \\
\hline UFVJM-52 & $1.14 \mathrm{~b}$ & S & $7.61 \mathrm{a}$ & MR & $2.33 d$ & S & $24.25 c$ & MoR \\
\hline UFVJM-53 & $0.29 a$ & $\mathrm{R}$ & $1.48 \mathrm{a}$ & MR & $4.64 \mathrm{e}$ & $S$ & $48.60 d$ & LR \\
\hline UFVJM-55 & $1.80 \mathrm{~b}$ & $S$ & $11.37 b$ & MoR & $0.14 a$ & $\mathrm{R}$ & $1.40 \mathrm{a}$ & MR \\
\hline UFVJM-56 & $0.08 a$ & $\mathrm{R}$ & $0.39 a$ & AR/I & $0.14 a$ & $\mathrm{R}$ & $1.41 \mathrm{a}$ & MR \\
\hline UFVJM-57 & $0.41 a$ & $\mathrm{R}$ & $1.96 a$ & MR & $3.45 \mathrm{e}$ & S & $32.07 c$ & LR \\
\hline UFVJM-59 & $0.76 a$ & $\mathrm{R}$ & $4.57 a$ & MR & $0.17 a$ & $\mathrm{R}$ & $1.77 a$ & MR \\
\hline UFVJM-60 & $1.19 \mathrm{~b}$ & S & $6.59 a$ & MR & $0.21 a$ & $\mathrm{R}$ & $2.16 \mathrm{a}$ & MR \\
\hline UFVJM-61 & $0.11 \mathrm{a}$ & $R$ & $0.50 a$ & AR/I & $0.04 a$ & $R$ & $0.49 a$ & $A R / I$ \\
\hline UFVJM-63 & $0.37 a$ & $\mathrm{R}$ & $1.91 \mathrm{a}$ & MR & $0.00 \mathrm{a}$ & $\mathrm{R}$ & $0.00 \mathrm{a}$ & AR/I \\
\hline Santa Clara & 21.22 & S & 100 & S & $10.47 f$ & S & 100 & S \\
\hline Média & 1.05 & & 5.77 & & 1.06 & & 10.55 & \\
\hline
\end{tabular}

${ }^{(1)}$ Means followed by the same letter in the column do not differ by the Scott-Knott test at $5 \%$ probability, Medium expressed based on the untransformed data. ${ }^{(2)} \mathrm{R}$, resistant; $\mathrm{S}$, susceptible. ${ }^{(3)}$ S, susceptible (Standard), IR above 51\%; LR slightly resilient, IR 26-50\%; Mor moderately resistant, IR 11-25\%; MR, very tough, IR 1\% to $10 \%$; AR / I, highly resistant / immune, IR below $1 \%$.

evaluated 123 sweet potato clones and obtained $46 \%$ of resistant clones by Oostenbrink classification (Oostenbrink, 1966), being classified as high resistance/immune (HR/I) and very resistant (VR) according to Taylor classification (Taylor, 1967). As well as Bassey (2012), who obtained $89 \%$ of clones as highly resistant and very resistant to M. incognita in southeastern Nigeria. Huang et al. (1986), evaluating a sweet potato collection of CNPH/EMBRAPA for $M$. incognita and $M$. javanica nematodes, obtained numerous resistance sources.

Considering two resistance classifications, and choosing as eligible for selection only clones at highly resistant/immune or very resistant classes according to Taylor (1967) and resistant to Oostenbrink (1966); therefore, $78 \%$ of evaluated clones may be considered fit for selection for Meloidogyne incognita race 1 .

As for M. incognita race 3, resistant and susceptible clone presence was also verified by Oostenbrink classification (Oostenbrink, 1966). Among the 63 evaluated clones, 13 (21\%) obtained values above unity for RF, being considered susceptible (Table 2). These values ranged from 1.50 (UFVJM-04 clone) to 10.50 (Batata-mandioca clone), which were higher than the one shown by tomato plants, considered as standard. Charchar \& Ritschel (2004) also observed similar proportions of susceptible clones assessing sweet potato germplasm bank of Embrapa Hortaliças for $M$. incognita race 3, and the authors found that only 49 of the 357 genotypes suffered nematode infection.

Still considering Oostenbrink (1966), it is verified that 50 clones (79\%) were classified as resistant and, as observed for $M$. incognita race 1 . These results are confirmed by Scott $\&$ Knott grouping since averages are separated into distinct groups of clones considered resistant from average obtained by control group.

Evaluated clones for $M$. incognita race 3 were distributed into all resistance classes according to Taylor (1967), (Table 2). A percentage of $79 \%$ of the clones were classified as highly resistant/immune (HR/I) and very resistant (VR). These clones were the same classified as resistant by Oostenbrink (1966) and, given the same selection level used for race 1, these clones are fit for selection for resistance to $M$. incognita race 3. Yet a percentage of $14 \%$ of the clones fell within slightly resistant (SR) and moderately resistant $\left(M_{O} R\right)$.

It is observed that among commercial cultivars, Brazlândia Rosada, Brazlândia Branca, Palmas and Coquinho were found to be resistant to both races by Oostenbrink classification (Oostenbrink, 1966), and obtained a high resistance degree (HR/I,MR) by Taylor (1967), while the Princesa was classified as susceptible and slightly resistant by the same classifications to both races (Table 2).

Charchar \& Ritschel (2004) conducting a study with Princesa cultivar showed a high degree of resistance to $M$. incognita races 1 and 3, while Coquinho obtained lower resistance levels, Brazlândia Rosada and Brazlândia Branca were considered susceptible to $M$. incognita race 1 . However, these results cannot be exactly comparable with those obtained in the current study because used methods for resistance classification present differences, since they are based on egg-mass number, symptom that is not 
necessarily expressed in sweet potato, potentially causing misinterpretations.

Regarding resistance to races 1 and 3, sweet potato clones showed different responses, in which $11 \%$ were eligible for selection for race 1 and susceptible to race 3; $13 \%$ fit for selection for race 3 and susceptible to race 1 ; $10 \%$ susceptible to both races; and $67 \%$ showed multiple resistance to both races (Table 2).

Considering that there are clones with resistance to race 1 and susceptibility to race 3 and vice versa, it can be inferred that different genes and/or alleles control the resistance against different M. incognita races (Cervantes-Flores et al., 2002; Ferreira et al., 2010; Maluf et al., 1996).

In general, both classifications were consistent to identify clones resistant to $M$. incognita races 1 and 3, but classification proposed by Taylor (1967) provided greater class distribution (HR/I, VR, MoR, LR and S), allowing more flexibility in classifying, while Oostenbrink (1966) classifies clones exclusively as resistant (R) or Susceptible (S). However, Oostenbrink (1966) is safer to select resistant clones, since it is based on initial and final number of nematode eggs. Contrary, Taylor classification (Taylor, 1967), which has its resistance classes obtained from ratio of nematode eggs involving a highly susceptible control.

According to Santos et al. (2012), special care should be taken in areas infested by nematodes and resistant clone selection is an efficient way to prevent future damage such as growth reduction, low production, besides symptoms that often upstage mineral deficiencies. Thus, $67 \%$ of the clones can be considered resistant to both races 1 and 3 by presenting resistance pattern according to Oostenbrink (1966) and highly resistant/immune and very resistant by Taylor classification (Taylor, 1967). Therefore, these clones are considered promising; since, according to Freitas et al. (2001), obtaining clones resistant to a great number of root-knot nematode species and races will enable enhanced security and acceptance by producers.

\section{CONCLUSION}

Clones present different resistance levels according to classifications of reproduction factor and reproduction index for both nematode races used.

Among the sweet potato clones, $78 \%$ are resistant to race $1,79 \%$ are resistant to race 3 , and $67 \%$ are resistant to both races.

There is genetic variability in UFVJM sweet potato germplasm bank regarding to resistance to $M$. incognita nematode races 1 and 3 .

The reproduction factor is the most useful in assessing resistance of sweet potato clones to races 1 and 3 .

\section{ACKNOWLEDGEMENTS}

We want to thank the Universidad Federal dos Vales do Jequitinhonha e Mucuri (UFVJM); to CAPES, CNPq and FAPEMIG; to the Universidade Federal de Lavras (UFLA); to HortiAgro Sementes SA; and the Olericulture Study Group/ UFVJM.

\section{REFERENCES}

Baldin, E. L. L., Wilcken, S. R. S., Pannuti, L. E. R., Schlick-Souza, E. C., \& Vanzei, F. P. (2012). Uso de extratos vegetais, manipueira e nematicida no controle do nematoide das galhas em cenoura. Summa Phytopathologica, 38, 36-41. http://dx.doi.org/10.1590/ S0100-54052012000100006.

Bassey, E. E. (2012). Field evaluation of yield and resistances of local and improved sweet potato (Ipomoea batatas (L) Lam) accessions to Cylas puncticollis and Meloidogyne incognita in Southeastern Nigeria. Asian Journal of Agricultural Sciences, 4, 390-394.

Cervantes-Flores, J. C., Yencho, G. C., \& Davis, E. L. (2002). Host reactions of sweet potato genotypes to root-knot nematodes and variation in virulence of Meloidogyne incognita populations. HortScience, 37, 1112-1116.

Charchar, J. M., \& Ritschel, P. S. (2004). Evaluation of germplasm bank of the sweet potato crop systems for resistance to Meloidogyne spp. Brasília: Embrapa Hortaliças.

Chaves, P. P. N., Santos, G. R. D., Silveira, M. A. D., Gomes, L. A. A., Momenté, V. G., \& Nascimento, I. R. (2013). Reaction of genotypes of the sweet potato to nematode galls in high temperature conditions. Bioscience Journal, 29, 1869-1877.

Cruz, C. D. (2013). GENES a software package for analysis in experimental statistics and quantitative genetics. Acta Scientiarum, 35, 271-276.

Ferreira, S., Gomes, L. A. A., Maluf, W. R., Campos, V. P., Carvalho, J. L. S. Fo., \& Santos, D. C. (2010). Resistance of dry bean and snap bean cultivars to root-knot nematodes. HortScience, 45, 320-322.

Freitas, J. A., Santos, G. C., Souza, V. S., \& Azevedo, S. M. A. (2001). Resistance of clones of sweet potato, Ipomoea batatas L., to the causative root-knot nematode. Acta Scientiarum, 23, 1257-1261.

Gonçalves, A. C. No., Maluf, W. R., Gomes, L. A. A., \& Maciel, G. M. (2012). Correlation and estimate population parameters for sweet potato. Horticultura Brasileira, 30, 713-719.

Huang, S. P., Miranda, J. E. C., \& Maluf, W. R. (1986). Resistance to root-knot nematodes in brazilian sweet potato collection. Fitopatologia Brasileira, 11, 761-767.

Hussey, R. S., \& Barker, K. R. (1973). A comparison of methods of collecting inocula of Meloidogyne spp. including a new technique. Plant Disease Reporter, 57, 1025-1028.

Hussey, R. S., Davis, E. L., \& Baum, T. J. (2002). Secrets in secretions: genes that control nematode parasitism of plants. Brazilian Journal 
of Plant Physiology, 14, 183-194. http://dx.doi.org/10.1590/S167704202002000300002 .

Jatala, P. (1991). Biology and management of plant-parasitic nematodes on sweet potato. In R.K. Jansson,. \& K.V. Raman. (Eds.), Sweet potato pest management: a global perspective 1991. New Delhi: Oxford and IBH Publishing.

Kalkmann, D. C., Peixoto, J. R., \& Nóbrega, D. S. (2013). Reação de clones de batata-doce à Meloidogyne incognita raças 1 e 4 e estimativa de parâmetros genéticos. Horticultura Brasileira, 31, 293-296. http:// dx.doi.org/10.1590/S0102-05362013000200019.

Maluf, W. R., Azevedo, S. M., \& Campos, V. P. (1996). Heritability of root knot nematode Meloidogyne spp.) resistance in sweet potatoes. Journal of Genetics \& Breeding, 50, 161-165.

Marchese, A., Maluf, W. R., Gonçalves, A. C. No, Gonçalves, R. D. S., \& Gomes, L. A. A. (2010). Seleção de clones de batata-doce resistentes a Meloidogyne incognita raça 1. Pesquisa Agropecuaria Brasileira, 45, 997-1004. http://dx.doi.org/10.1590/S0100-204X2010000900009.

Marino, R. H., Gomes, L. A. A., Cruz, E. M. O., Silva, A. D. C., Bianchini, F. G., Meneses, T. N., \& Blank, A. F. (2012). Controle de Meloidogyne incognita raça 1 com óleo essencial de Lippia Alba. Scientia Plena, 8, 1-8.

Massaroto, J. A., Gomes, L. A. A., Maluf, W. R., Silva, R. R., \& Gomes, A. R. V. A. (2010). Reação de clones de batata-doce ao Meloidogyne incognita raça 1. Revista de Ciências AgroAmbientais, 8, 1-8.
Michereff, S. J., Andrade, D. E. G. T., \& Menezes, M. (Eds.). (2005). Ecology and management of root pathogens in tropical soils. Recife: Imprensa Universitária da Universidade Federal Rural de Pernambuco.

Neves, W. D. S., Dallemole-Giaretta, R., Zooca, R. J. F., \& Coutinho, M. M. (2010). Effect of botanical extracts on hatching and inactivation of juvenile Meloidogyne javanica e de M. incognita. Revista Trópica. Ciências Agrárias e Biológicas, 4, 8.

Oliveira, A. P., Silva, J. E. L., Pereira, W. E., \& Barbosa, L. J. N. (2005). Produçáo de batata-doce e teor de amido nas raízes em função de doses de P2O5. Acta Scientiarum. Agronomy, 27, 747-751.

Oostenbrink, M. (1966). Major characteristics of the relation between nematodes and plants. (Mededelingen Van De landbouwhogeschool Te Wageningen, 66). Nederland: H. Veenman \& Zonen.

Rosa, J. M. O, Westerich, J. N., \& Wilcken, S. R. S. (2013). Meloidogyne javanica reproduction on vegetable crops and plants used as green manure. Tropical Plant Pathology, 38, 133-141. http:// dx.doi.org/10.1590/S1982-56762013000200007.

Santos, L. N. S., Alves, F. R., Belan, L. L; Cabral, P. D. S., Matta, F. P., Jesus, W. C. Jr., \& Moraes, W. B. (2012). Damage quantification and reaction of bean genotypes (Phaseolus vulgaris L.) to Meloidogyne incognita race 3 and M. javanica. Summa Phytopathologica, 38, 24-29.

Taylor, A. L. (1967). Introduction to research on plant nematology: an FAO guide to study and control of the plantparasitic nematodes. Rome: Food And Agricultural Organization of the United Nations. 